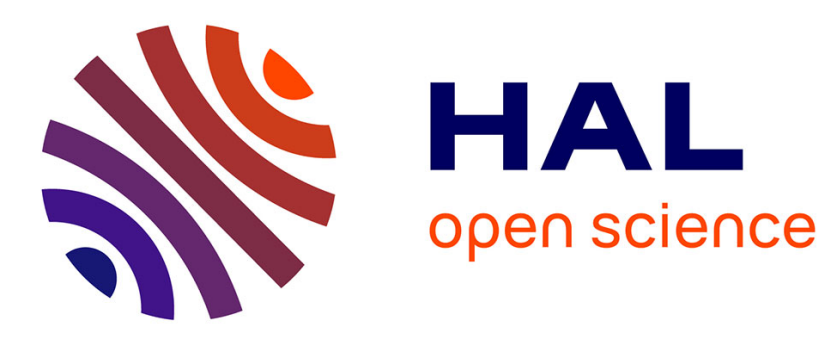

\title{
Bioaccessibility and digestibility of lipids from food
}

\author{
Myriam M.-L. Grundy, Peter J. Wilde
}

\section{To cite this version:}

Myriam M.-L. Grundy, Peter J. Wilde. Bioaccessibility and digestibility of lipids from food. Springer International Publishing, 231 p., 2021, 978-3-030-56908-2. 10.1007/978-3-030-56909-9 hal03241378

\section{HAL Id: hal-03241378 \\ https://hal.inrae.fr/hal-03241378}

Submitted on 28 May 2021

HAL is a multi-disciplinary open access archive for the deposit and dissemination of scientific research documents, whether they are published or not. The documents may come from teaching and research institutions in France or abroad, or from public or private research centers.
L'archive ouverte pluridisciplinaire HAL, est destinée au dépôt et à la diffusion de documents scientifiques de niveau recherche, publiés ou non, émanant des établissements d'enseignement et de recherche français ou étrangers, des laboratoires publics ou privés. 
Bioaccessibility and Digestibility

of Lipids from Food 
Myriam M.-L. Grundy • Peter J. Wilde Editors

\section{Bioaccessibility and Digestibility of Lipids from Food}

照 Springer 


\author{
Editors \\ Myriam M.-L. Grundy \\ PEGASE, INRAE \\ Institut Agro \\ Saint Gilles, France
}

Peter J. Wilde

Norwich Research Park

Quadram Institute Bioscience

Norwich, UK

\section{ISBN 978-3-030-56908-2 ISBN 978-3-030-56909-9 (eBook) https://doi.org/10.1007/978-3-030-56909-9}

(C) Springer Nature Switzerland AG 2021

This work is subject to copyright. All rights are reserved by the Publisher, whether the whole or part of the material is concerned, specifically the rights of translation, reprinting, reuse of illustrations, recitation, broadcasting, reproduction on microfilms or in any other physical way, and transmission or information storage and retrieval, electronic adaptation, computer software, or by similar or dissimilar methodology now known or hereafter developed.

The use of general descriptive names, registered names, trademarks, service marks, etc. in this publication does not imply, even in the absence of a specific statement, that such names are exempt from the relevant protective laws and regulations and therefore free for general use.

The publisher, the authors, and the editors are safe to assume that the advice and information in this book are believed to be true and accurate at the date of publication. Neither the publisher nor the authors or the editors give a warranty, expressed or implied, with respect to the material contained herein or for any errors or omissions that may have been made. The publisher remains neutral with regard to jurisdictional claims in published maps and institutional affiliations.

This Springer imprint is published by the registered company Springer Nature Switzerland AG The registered company address is: Gewerbestrasse 11, 6330 Cham, Switzerland 


\section{Contents}

\section{Part I Digestion of Lipids}

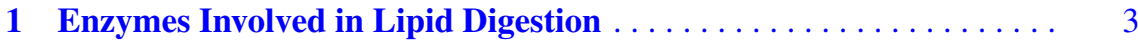

A. Salhi, F. Carriere, Myriam M.-L. Grundy, and A. Aloulou

2 Lipid Digestion as a Colloid and Interface Phenomena . . . . . . . . . 29 David Julian McClements

3 Lipid Digestion: In Vitro and In Vivo Models and Insights . . . . . . . 47 Dafna Meshulam Pascoviche and Uri Lesmes

\section{Part II Lipid Metabolism}

4 Oral Processing of Lipids

Miodrag Glumac, Xinmiao Wang, and Jianshe Chen

5 Physiological Aspects of Lipid Digestion: Luminal and Mucosal Events

Alan Mackie

6 Lipids and Cardiovascular Disease Risks with a Focus on Dairy Foods

D. I. Givens

\section{Part III Food Structure}

7 Plant Food Structure and Lipid Digestibility .

Myriam M.-L. Grundy and Peter J. Wilde

8 Dairy Products.

A. -I. Mulet-Cabero and A. Brodkorb

9 Interactions Among Macronutrients and Their Effect on Lypolisis

A. Heredia, A. Asensio-Grau, J. Calvo-Lerma, and A. Andrés 


\section{Part IV Other Forms of Lipids}

10 Lipid Digestion and Bioaccessibility of Lipid-Soluble Compounds .

Ali Rashidinejad, Sébastien Marze, and Harjinder Singh

11 Sterol Digestion in Plant Sterol-Enriched Foods:

Bioaccessibility and Fermentation. . . . . . . . . . . . . . 205

Virginia Blanco-Morales, Guadalupe Garcia-Llatas, and Antonio Cilla

Conclusion

Index. 


\section{Introduction}

Although evidence exists on the health benefits associated with the inclusion of certain lipid-rich foods (e.g. nuts, dairy products and fish) in the diet, the mechanisms that explain the physiological effects and the long-term benefits are not well understood. Lipids in themselves are essential nutrients and have many beneficial health effects: they are a source of energy and essential fatty acids, they are structural components of cell membranes, they are required to solubilise fat soluble compounds, and they serve as precursors of hormones. In general, it is only when dietary lipids are consumed in excess that they begin to have a negative impact on our health. The nutritional quality of our diet has a huge influence on our health and well-being, with a plethora of conditions and diseases being associated with a poor diet. It is becoming increasingly apparent that the nutritional quality of our food is a consequence of not only its nutritional composition but also how its structure influences the rate and extent of nutrient availability. The structure of a food influences the way it is transformed during processing and digestion. This, in turn, has an impact on nutrient bioaccessibility (release) and digestibility, and subsequently on the physiological response and health of the individual who consumes that food. Hence, care needs to be taken when assessing nutritional quality based purely on nutrient composition.

Lipids are generally insoluble in water; therefore, to be digested, lipids are required to be dispersed or emulsified to make them more accessible to the lipases which hydrolyse them into components suitable for absorption, for instance, by being released from the food matrix (from the cells of a plant tissue). The rate and extent of lipid digestion is governed by the way lipids are "presented" to the lipases in the different compartments of the gastrointestinal tract. Lipid digestion can be viewed as a colloidal and interfacial phenomenon where digestive agents (e.g. bile salts and lipases) and food components (e.g. dietary fibres, proteins and phytosterols) interact with the lipid at the lipid-water interface and thereby impact their hydrolysis by lipase(s).

Diets containing foods high in fat are considered to be detrimental to health; however, studies have shown that the consumption of certain foods which are high in fat, such as nuts and certain dairy products, led to beneficial effects on risk factors 
for cardiovascular disease. A great proportion of lipid in some food matrices, such as almonds, remains undisturbed after mastication and the subsequent digestion processes. Here, the plant cell walls are resistant to digestion in the upper gastrointestinal tract and therefore encapsulate intracellular nutrients, thereby limiting lipid bioaccessibility. In dairy products, the structure of the food matrix can also have an impact on lipid digestibility. Indeed, the composition, microstructure and rheological properties of cheese matrices have been shown to impact the kinetics of the degradation of the cheese and the digestibility of the lipid it contained. Regarding food products where the lipids are readily available, such as milk and plant-based beverages or soups, other parameters can dictate lipid digestibility. These include the size of the droplets and the "quality" of the droplets interface (i.e. surface-active molecules) and the presence of certain compounds that may inhibit lipase activity (e.g. dietary fibres).

Therefore, the overall structure of the food containing the lipids is likely to also play a crucial role, notably by influencing their bioaccessibility and digestibility and ultimately their impact on nutrition and health.

This book aims to cover some of the latest research performed on food structure in the context of lipid digestion. The subjects include lipases, in vitro and in vivo models used to monitor lipid digestion, physiological aspects of lipid digestion and the impact of food structure (plant and animal sources of lipids). 